\title{
Assessment of small bowel function in the elderly using a modified xylose tolerance test
}

\author{
S. G. P. WEBSTER AND J. T. LEEMING \\ From the Department of Geriatric Medicine, Chesterton Hospital, Cambridge
}

SUMMARY Using the combined results of oral and intravenous xylose tests, it is demonstrated that $26 \%$ of a group of geriatric patients absorb from the small bowel less efficiently than younger subjects.

The method used excludes poor renal function and incomplete bladder emptying as possible causes for the differences found between the two age groups. Altered gastric emptying is also excluded as a possible factor.

Phillips and Gilder (1940) reported reduced absorption of dextrose in aged rats when direct measurements were made on luminal residues after an oral load. In man, Meyer, Sorter, Oliver, and Necheles (1943) were probably the first workers to present evidence suggestive of impaired small bowel function in the elderly in relation to theabsorption of monosaccharides. Their findings were based on the results of observing blood galactose levels in elderly subjects after oral ingestion of galactose. Although slow removal of galactose from the subjects' blood could account for the differences between their young and elderly groups, the initial low levels found only in the elderly could have been caused by the impaired absorption of the monosaccharide.

Guth (1968), using similar reasoning to Meyer et $a l$, concluded from the xylose tests that he performed that small bowel absorption was impaired in the elderly. (However, both groups' conclusion can be criticized, as impaired renal function was not actively excluded and could therefore be influencing their results.) Davies and Shock (1950), Dontas (1963), and Friedman, Raizner, Rosen, Solomon, and Sy (1972) all clearly demonstrated by different methods the frequency of renal functional impairment with increasing age.

Sapp, Seasions, and Rose (1964) and Fikry and Aboul-Wafa (1965) attempted to exclude elderly subjects with subnormal renal function from their studies on the effects of age on the standard xylose test, and found a decrease in urinary recovery of the substance after an oral dose.

Received for publication 18 September 1974.
Kendall (1970) and Kendall and Nutter (1970) described a combined oral and intravenous xylose test which effectively measured small bowel function irrespective of renal function by determining the ratio between the amount of xylose recovered in the urine after an oral dose and the amount recovered after intravenous administration.

\section{Patients}

The $85^{\circ}$ patients studied were selected from those admitted from the lists to a busy geriatric unit. All were aged over 63 years (eldest $95 \mathrm{yr}$ ) with a mean age of 81 years. The majority had been admitted to hospital because of the results of cerebrovascular disease and a minority because of an acute exacerbation of various chronic disorders. As expected in such a group, social problems were common and had also contributed to the necessity for hospital admission. No patients with known small bowel disease or suggestive symptoms were included. Patients with a diagnosed neoplastic lesion or ascites were excluded, as reports of impaired absorption or interference with the xylose test have been published (Creamer 1964; Hindle and Creamer, 1965; Dymock, MacKay, Miller, Thomson, Gray, Kennedy, and Adams, 1967; Mann, 1968; Marin, Clark, and Senior, 1968).

No acutely ill patients were studied, and urinary incontinence obviously made many patients unsuitable unless they already had an indwelling catheter, as in 16 cases.

For comparison, a younger group of ages ranging from 18 to 35 years (mean 25 years) was also studied. 
These were all patients admitted to an orthopaedic ward for treatment of sport or road traffic accidents with the exception of two members of the hospital staff.

\section{Methods}

In preparation for the xylose tests, subjects were fasted for at least eight hours and only water was allowed by mouth throughout the duration of the test.

For the oral tests, $25 \mathrm{~g}$ of d-xylose was given dissolved in $200 \mathrm{ml}$ of water. Subjects were then given a further $200 \mathrm{ml}$ of water and encouraged to take up to a further $400 \mathrm{ml}$, depending on capacity, during the test period of five hours.

In the intravenous tests performed, $5 \mathrm{~g}$ of xylose in a $10 \%$ solution was injected slowly over two to three minutes, and the subject was then given water to drink as in the oral test (with a minimum intake of $400 \mathrm{ml}$ ).

Urine was collected for five hours after xylose administration, the total volume measured, and a small sample reserved for analysis of the xylose content. In 22 elderly patients, the urine was collected separately for the first two hours of the intravenous test when possible.

All estimations of xylose concentration were made by the method of Roe and Rice (1948) either on the same day as the test or the specimens were deep frozen at $-20^{\circ} \mathrm{C}$ until the time of analysis.

For each subject studied, a xylose absorption test ratio was calculated, as suggested by Kendall (1970), by dividing the result of the urinary recovery of xylose during five hours after the oral test by the result following the intravenous administration of xylose.

In six of the geriatric patients, the $5 \mathrm{~g}$ intravenous test was repeated in the non-fasting state, and, during the second test, the patient was also allowed to eat freely.

Gastric emptying times were compared in young and old subjects. There were 10 members in each group: the mean age of the young was 30 years (range 23 to 43 ) and the mean of the elderly was 78 years (range 66 to 83 years). Observations were made on abdominal screening with a portable image intensifier 90 minutes after the ingestion of $25 \mathrm{~g}$ of xylose mixed with $125 \mathrm{ml}$ of water and $60 \mathrm{ml}$ of Micropaque. Screening was continued at 15-minute intervals until the stomach was empty or until two hours after the drinking of the test meal.

\section{Results}

Mean urinary recoveries of xylose in five hours after oral ( $25 \mathrm{~g})$ and intravenous (5 g) administration are shown in table I for the young controls and 85 geriatric patients. The distribution of xylose absorption test ratios in the patients and in the

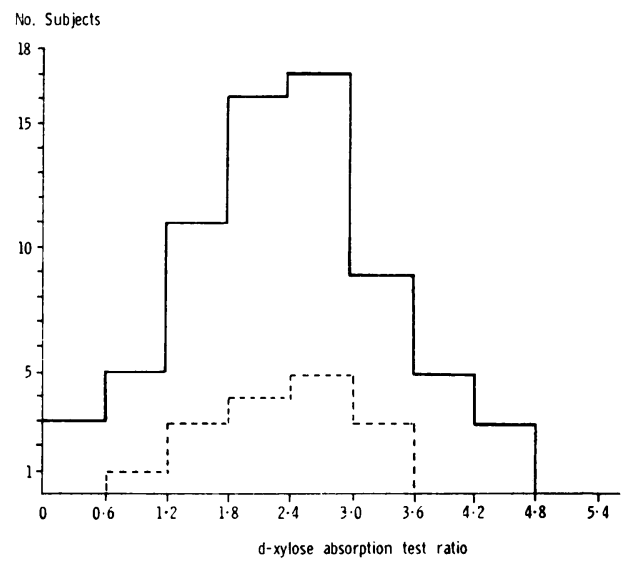

Fig 1 Distribution of d-xylose test ratios in 85 elderly patients. $-=$ Patients without catheters; -- -- = patients with catheters.

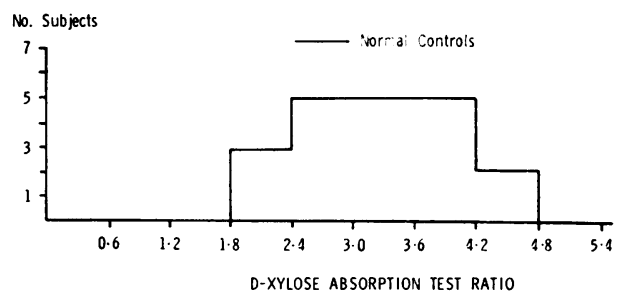

Fig 2 The distribution of the d-xylose absorption test ratio in 20 young controls.

\begin{tabular}{|c|c|c|c|c|c|}
\hline Subject & & Years of Age & $\begin{array}{l}\text { Five-hour Recovery } x \\
(25 \mathrm{~g} \text { orally) }\end{array}$ & $\begin{array}{l}\text { Five-hour recovery y } \frac{x}{y} \\
(5 g \text { iv) }\end{array}$ & $\frac{x}{y}$ \\
\hline $\begin{array}{l}69 \text { patients without } \\
\text { catheters } \\
16 \text { patients with } \\
\text { catheters } \\
20 \text { young controls }\end{array}$ & $\begin{array}{l}\text { Mean } \\
\text { Range } \\
\text { Mean } \\
\text { Range } \\
\text { Mean } \\
\text { Range }\end{array}$ & $\begin{array}{c}81 \\
(63-94) \\
84 \\
(73-95) \\
25 \\
(18-35)\end{array}$ & $\begin{array}{c}3 \cdot 2 \\
(0 \cdot 1-7 \cdot 3) \\
3 \cdot 5 \\
(0 \cdot 7-6 \cdot 5) \\
6 \cdot 9 \\
(3 \cdot 7-9 \cdot 0)\end{array}$ & $\begin{array}{c}1 \cdot 3 \\
(0 \cdot 4-2 \cdot 5) \\
1 \cdot 4 \\
(0 \cdot 5-2 \cdot 4) \\
2 \cdot 1 \\
(1 \cdot 1-2 \cdot 7)\end{array}$ & $\begin{array}{c}2389 \\
(0 \cdot 250-4 \cdot 444) \\
2 \cdot 387 \\
(0 \cdot 875-3 \cdot 461) \\
3 \cdot 288 \\
(2 \cdot 056-4 \cdot 723)\end{array}$ \\
\hline
\end{tabular}

Table I Mean urinary recoveries in 20 young and 85 elderly subjects and the mean d-xylose absorption test ratios 


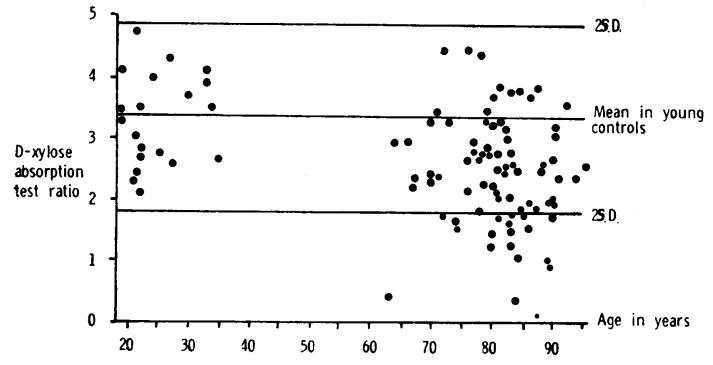

Fig 3 The distribution of $d$-xylose absorption test ratios according to age.

control group is shown in figs 1 and 2 and the two groups are compared in figure 3.

In the 22 geriatric patients where the amount of urine passed in the first two hours of their test was collected, no specimen could be obtained in six cases. In the remainder, the volume collected was frequently very small and the xylose content low $(0.1$ to $0.9 \mathrm{~g}$, mean $0.49 \mathrm{~g})$.

The effect of fasting on the intravenous xylose test in six geriatric patients is shown in table II.

\begin{tabular}{lll}
\hline Fasting & Not Fasting & Difference \\
\hline 1.8 & 1.5 & 0.3 \\
1.4 & 0.9 & 0.5 \\
1.3 & 0.8 & 0.5 \\
1.9 & 0.8 & 1.1 \\
1.3 & 1.1 & 0.2 \\
1.9 & 1.3 & 0.6 \\
\hline 1.60 & 1.07 & 0.53 \\
\hline
\end{tabular}

Table II Five-hour urine recoveries of $d$-xylose after

$5 \mathrm{~g}$ iv in fasting and non-fasting states

The rate of gastric emptying in both young and old subjects is shown in table III.
Our attempts to obtain urine specimens from geriatric patients two hours after $5 \mathrm{~g}$ of xylose intravenously were so unsuccessful that the test became impossible in the elderly. We therefore returned to the better established method of collecting urine for five hours. As an oral dose of $5 \mathrm{~g}$ is completely absorbed from the normal small bowel (McCance and Madders, 1930) when assessed from five hourly urine collections, we considered that the more traditional oral load of $25 \mathrm{~g}$ would be a more thorough test of absorption from the small bowel.

In 69 elderly subjects over 63 years, the mean xylose absorption test ratio (calculated by dividing the five-hour urinary recovery after $25 \mathrm{~g}$ of xylose by mouth by the result obtained after a $5 \mathrm{~g}$ intravenous dose) was 2.389 (range 0.250 to 4.444 ). The mean ratio in the remaining 16 geriatric patients who had a bladder catheter in situ was 2.387 (range 0.875 to 3.461 ). The difference between these two elderly groups was not statistically significant ( $P>10 \%$ using Wilcoxon's sum of ranks test).

In the 20 young controls the mean ratio (calculated from the results of the oral and intravenous test) was 3.288 (range 2.056 to $4 \cdot 723$ ). Comparisons between either elderly group (with or without catheters) and the young controls, using Wilcoxon's sum of ranks test, reveals that the ratio in the younger group is significantly higher: young controls $\mathbf{v}$ elderly without catheter, $\mathrm{P}<0.2 \%$; young controls v elderly with catheter, $\mathrm{P}<1 \%>0.2 \%$.

The observations made on gastric emptying after a large oral dose of xylose demonstrated no differences between the old and young groups.

The results of five hourly urinary recovery after intravenous xylose tests in aged subjects were found to be significantly higher in fasting subjects using Wilcoxon's sum of ranks test ( $\mathrm{P}<5 \%>1 \%)$.

\begin{tabular}{|c|c|c|c|c|}
\hline \multirow[t]{2}{*}{ Subject } & \multirow[t]{2}{*}{ Mean Age (yr) } & \multicolumn{3}{|c|}{ Time of Gastric Emptying in Minutes } \\
\hline & & $90-105$ & $105-120$ & $120+$ \\
\hline $\begin{array}{l}\text { Young } \\
\text { Elderly }\end{array}$ & $\begin{array}{l}30 \\
78\end{array}$ & $\begin{array}{l}5 \\
7\end{array}$ & $\begin{array}{l}3 \\
1\end{array}$ & $\begin{array}{l}2 \\
1\end{array}$ \\
\hline
\end{tabular}

Table III Number of subjects with complete gastric emptying in minutes after ingestion of $25 \mathrm{~g}$ of $d$-xylose with water and barium

\section{Discussion}

Kendall (1970) in his description of the use of both oral and intravenous xylose tests advocated the practice of two-hourly urine collections after each dose and recommended an oral load of only $5 \mathrm{~g}$.

\section{Conclusions}

Our findings indicate that the absorption of $d-$ xylose from the small bowel is impaired in old age. The ability to absorb this monosaccharide is very variable in aged subjects, but $26 \%$ of those elderly 
subjects studied had a xylose test absorption ratio below the calculated normal range of 25 young subjects (mean $\pm 2 \mathrm{SD}$, ie, 1.8 to $4 \cdot 8$ ). Only $16 \%$ of the geriatric patients had ratios greater than the mean calculated for the young controls.

In most old people with a subnormal ratio, the impairment is not as severe as in patients with coeliac disease or tropical sprue. Using the results of Stewart, Pollock, Hoffbrand, Mollin, and Booth (1967), Finlay and Wightman (1958), Benson, Culver, Ragland, Jones, Drummey, and Bougas, (1957), Gardner and Santiago (1956), Christiansen, Kirsner, and Ablaza (1959), and Shiner, Vakil, and Wilcox (1962), in combination with results for the intravenous test in young subjects found in the present study, the calculated xylose absorption test ratio in patients with either coeliac disease or tropical sprue would be 0.6 to 1.2 with a weighted mean of $1 \cdot 1$. However, only $7 \%$ of the elderly subjects studied in this series had a ratio of less than 1.2.

The use of the xylose test in the aged is often criticized on three counts: (1) Renal function is impaired, but the method used in the present work has been devised to overcome this difficulty. (2) A large residual bladder capacity, but the present comparison between elderly patients with and without bladder catheters gave similar results. (3) The validity of the test is dependent on the rate of gastric emptying, but it has been possible to show that this is unchanged for carbohydrates in the elderly.

However, Kendall (1970) concluded from studies using both oral and intravenous doses of xylose that absorption of the monosaccharide was not impaired in the elderly. Possible explanations for the different conclusions reached by Kendall and ourselves are first the differences in ages of the two elderly groups. Kendall's patients were considerably younger with only three subjects over 70 years of age and 14 aged from 61 to 70 . Another fundamental difference was the fact that Kendall did not enforce any dietary restrictions on subjects undergoing the intravenous test. From the work of Dominguez and Pomerene (1934), it might have been anticipated that this would have influenced the amount of xylose recovered from the urine. The studies in the present series confirm that starvation before and throughout the test is essential if true comparisons are to be made between the oral and intravenous methods of administering xylose.

Opinion is divided as to whether the oral $5 \mathrm{~g}$ or $25 \mathrm{~g}$ dose of xylose is the most efficient test of small bowel function, but as an oral dose of $5 \mathrm{~g}$ can be completely absorbed as shown by the results of McCance and Madders (1930), Joske and Haagensen (1964) and Sammons, Morgan, Frazer, Montgomery, Philip, and Phillips (1967), it is difficult to believe that it can test maximum efficiency. Joske and Haagensen (1964) and Rinaldo and Gluckman (1964) compared results, using both doses and decided that the larger $(25 \mathrm{~g})$ was a more sensitive test of small bowel function. This difference in oral dosage may therefore provide a further explanation for the variance between the present results and those of Kendall in aged subjects.

This work was carried out by S. G. P. Webster whilst holding a research grant provided by Manchester Regional Hospital Board and forms part of a thesis accepted by the University of London for the degree of MD.

\section{References}

Benson, J. A., Jr., Culver, P. J., Ragland, S., Jones, C. M., Drummey, G. D., and Bougas, E. (1957). The d-xylose absorption test in malabsorption syndromes. New Engl. J. Med., 256, 335-339.

Christiansen, P. A., Kirsner, J. B., and Ablaza, J. (1959). D-xylose and its use in the diagnosis of malabsorptive states. Amer. $J$. Med., 27, 443-453.

Creamer. B. (1964). Malignancy and the small-intestinal mucosa. Brit. med. J., 2, 1435-1436.

Davies, D. F., and Shock, N. W. (1950). Age changes in glomerular filtration rate, effective renal plasma flow and tubular excretary capacity in adult males. J. clin. Invest., 29, 496-507.

Dominguez, R., and Pomerene, E. (1934). On the renal excretion of xylose. J. clin. Invest., 13, 753-766.

Dontas, A. S. (1963). Ageing trends in renal function. In Age with a Future: Proceedings of the VIth. International Congress of Gerontology, 1963, ecited by P. F. Hansen, pp. 196-202. Munksgaard, Copenhagen.

Dymock, I. W., MacKay, N., Miller, V., Thomson, T. J., Gray, B., Kennedy, E. H., and Adams, J. F. (1967). Small intestinal function in neoplastic disease. Brit. J. Cancer, 21, 505-511.

Fikry, M. E., and Aboul-Wafa, M. H. (1965). Intestinal absorption in the old. Geront. Clin., 7, 171-178.

Finlay, J. M., and Wightman, K. J. R. (1958). The xylose tolerance test as a measure of the intestinal absorption of carbohydrate in sprue. Ann. Intern. Med., 49, 1332-1347.

Friedman, S. A., Raizner, A. E., Rosen, H., Solomon, N. A., and Sy, W. (1972). Functional defects in the ageing kidney. Ann. Intern. Med., 76, 41-45.

Gardner, F. H., and Santiago, E. P. (1956). Oral absorption tolerance tests in tropical sprue. Arch. intern. Med., 98, 467474.

Guth, P. (1968). Physiologic alterations in small bowel function with age. Amer. J. dig. Dis., 13, 565-571.

Hindle, W., and Creamer, B. (1965). Significance of a flat small intestinal muccsa. Brit. med. J., 2, 455-458.

Joske, R. A., and Ha agensen, L. J. (1964). The 5G d-xylose absorption test. J. clin. Path., 17, 154-155.

Kendall, M. J. (1970). The influence of age on the xylose absorption test. Gut, 11, 498-501.

Kendall, M.J., and Nutter, S. (1970). The influence of sex, body-weight, and renal function on the xylose test. Gut, 11, 1020-1023.

Marin, G. A., Clark, M. L., and Senior, J. R. (1968). Distribution of d-xylose in sequestered fluid resulting in false-positive tests for malabsorption. Ann. intern. Med., 69, $1155-1162$.

McCance, R. A., and Madders, K. (1930). The comparative rates of absorption of sugars from the human intestine. Biochem. J., 24, 795-804.

Meyer, J., Sorter, H., Oliver, J., and Necheles, H. (1943). Studies in old age VII. Intestinal absorption in old age. Gastroenterology, 1, 876-881.

Phillips, R. A., and Gilder, H. (1940). Metabolism studies in the albino rat: the relation of age, nutrition and hypophysectomy on the absorption of dextrose from the gastrointestinal tract. Endocrinology, 27, 601-604.

Rinaldo, J. A., Jr., and Gluckmann, R. F. (1964). Maximum absorp- 
tion capacity for xylose in nontropical sprue. Gastroenterology, 47, 248-250.

Roe, J. H., and Rice, E. W. (1948). A photometric method for the determination of free pentoses in animal tissues. J. biol. Chem. 173, 507-512.

Sammons, H. G., Morgan, D. B., Frazer, A. C., Montgomery, R. D., Philip, W. M., and Phillips, M. J. (1967). Modifications in the xylose absorption test as an index of intestinal function. Gut, 8 348-353.
Sapp, O. L., Seasions, J. T., and Rose, J. W., Jr., (1964). Effect of ageing on intestinal absorption of sugars. Clin. Res., 12, 31.

Shiner, M., Vakil, B. J., and Wilcox, P. B. (1962). Urinary xylose excretion in steatorrhoea. Gut, 3, 240-244.

Stewart, J. S., Pollock, D. J., Hoffbrand, A. V., Mollin, D. L., and Booth, C. C. (1967). A study of proximal and distal intestinal structure and absorptive function in idiopathic steatorrhoea. Quart. J. Med., 36, 425-444.

\section{The January 1975 Issue}

\section{THE JANUARY 1975 ISSUE CONTAINS THE FOLLOWING PAPERS}

Biliary lipid output during three meals and an overnight fast

I Relationship to bile acid pool size and cholesterol saturation of bile in gallstone and control subjects T. C. NORTHFIELD AND A. F. HOFMANN

II Effect of chenodeoxycholic acid treatment in gallstone subjects T. C. NORTHFIELD, N. F. LARUSSO, A. F. HOFMANN, AND J. L. THISTLE

Subepithelial collagen in intestinal malabsorption R. BOSSART, K. HENRY, C. C. BOOTH, AND WILLIAM F. DOE

A method to study cell proliferation kinetics in human gastric mucosa O. HART HANSEN, T. PEDERSEN, AND J. K. LARSEN

Duodenogastric reflux: A cause of gastric mucosal hyperaemia and symptoms after operations for peptic ulceration M. R. B. KEIGHLEY, P. ASQUITH, AND J. ALEXANDER-WILLIAMS

Effect of metiamide on the response to secretin and cholecystokinin in man B. THJODLEIFSSON AND K. G. WORMSLEY
Rectal potential difference in the diagnosis of aldosterone excess D. G. BEEVERS, J. J. MORTON, M. TREE, AND JESSIE YOUNG

Colonic and small intestinal response to intravenous prostaglandin $F_{2 \alpha}$ and $E_{2}$ in man G. J. MILTONTHOMPSON, J. H. CUMMINGS, A. NEWMAN, J. A. BILLINGS, AND J. J. MISIEWICZ

The effect of intravenous prostaglandin $\mathrm{F}_{2 \alpha}$ and $\mathrm{E}_{2}$ on the motility of the sigmoid colon R. H. HUNT, J. B. DILAWARI, AND J. J. MISIEWICZ

Small bowel extracts in the inhibition of tumour growth P. CHAN, K. C. CALMAN, AND T. A. CONNORS

Deoxycholate depresses small-intestinal enzyme activity MICHAEL GRACEY, MURRAY HOUGHTON and JENNIFER THOMAS

Posterior mediastinal venous masses in patients with portal hypertension P. J. A. MOULT, D. W. WAITE, AND R. DICK

Epidemiological aspects of Crohn's disease in Clydesdale 1961-1970 I. S. SMITH, S. YOUNG, G. GILLESPIE, J. o'CONNOR, AND J. R. BELL

\section{Progress report}

Elemental diets R. I. RUSSELL

Notes and activities

Copies are still available and may be obtained from the PUBLISHING MANAGER,

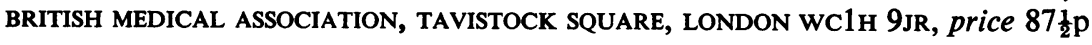

